Cakrawala Dini: Jurnal Pendidikan Anak Usia Dini | p-ISSN 2087-I317 | e-ISSN 262I-8321

Vol. 9. No.2 November 2018 | Hal 63-74

\title{
ANALISIS SUBJECTIF WELL-BEING ANAK USIA DINI YANG BERASAL DARI KELUARGA BERSTATUS EKONOMI SOSIAL RENDAH DI KOTA PEKANBARU
}

\author{
Sri Wahyuni ${ }^{1}$, Reswita ${ }^{2}$, Heleni Filtri ${ }^{3}$ \\ Universitas Lancang Kuning
}

\begin{abstract}
Factors that can affect the child is the level of happiness of children with the condition of his family. Like the attention of parents, facilities, and so on which children have. The tendency that happens is that children from poor families have a low assessment of the happiness of his life. The level or level of happiness that an individual perceives will be different from other individuals. This is influenced by the things that make the individual happy like a harmonious family, friends or a warm environment, socioeconomic status, and so on. But often a person's happiness is measured only on the basis of basic needs such as clothing, food, and shelter. The purpose of this study is to know and analyze the level of Subjective Well Being of Early Childhood Originating from the Family of Low Social Economy in Pekanbaru City. The research method used is quantitative descriptive by using statistical analysis. Based on the findings of the research, it is found that high well-being subjectif well-being wellbeing rate even from low-income families.
\end{abstract}

Keyword: Subjective well-being, early childhood, poor family

\begin{abstract}
Abstrak: Faktor yang dapat mempengaruhi anak adalah tingkat kebahagiaan anak dengan kondisi keluarganya. Seperti perhatian orangtua, fasilitas, dan sebagainya yang anak miliki. Kecenderungan yang terjadi adalah anak yang berasal dari keluarga miskin memiliki penilaian yang rendah terhadap kebahagiaan hidupnya. Tingkatan atau kadar kebahagiaan yang dirasakan individu satu akan berbeda dengan individu lain. Hal ini dipengaruhi oleh hal-hal yang menjadikan individu tersebut bahagia seperti keluarga yang harmonis, temanteman atau lingkungan yang hangat, status sosial ekonomi, dan sebagainya. Namun seringkali kebahagiaan seseorang hanya diukur berdasarkan keterpenuhan kebutuhan dasar saja seperti kebutuhan sandang, pangan, dan papan. Tujuan penelitian ini adalah untuk mengetahui dan menganalisis tentang tingkat Subjective well Being Anak Usia dini yang Berasal dari Keluarga Berstatus ekonomi Sosial yang Rendah di Kota Pekanbaru. Metode penelitian yang digunakan adalah kuantitatif deskriptif dengan menggunakan analisis statistik. Berdasarkan temuan penelitian diperoleh hasil bahwa tingkat kesejahteraan subjectif well-being anak usia dini tinggi meskipun berasal dari keluarga berstatus ekonomi rendah
\end{abstract}

Kata Kunci: Subjective well-being, anak usia dini, keluarga miskin

\section{PENDAHULUAN}

Statistik Kota Pekanbaru pada tahun 2016, garis kemiskinan di Kota pekanbaru selama kurun waktu 2001-
2010 mengalami peningkatan yaitu pada tahun 2001 penduduk miskin di Kota Pekanbaru berjumlah 38.200 jiwa sampai pada tahun 2010 berjumlah 52.700 jiwa.

\footnotetext{
'Universitas Lancang Kuning, Email: sriwahyuni919国unlak.ac.id

2Universitas Lancang Kuning, Email: reswita国unilak.ac.id

${ }^{3}$ Universitas Lancang Kuning, Email: helenifiltri国unilak.ac.id
} 
Pada tahun 2011 garis kemiskinan Kota Pekanbaru tercatat sebesar 326.705 atau naik sebesar 6,73\% dari tahun 2010. Berikutnya dari sumber yang sama diperoleh persentase rumah tangga miskin Kota Pekanbaru pada kategori hampir miskin (berpotensi untuk menjadi miskin) adalah 51,69\%, kategori miskin 37,31\%, dan kategori sangat miskin adalah $11,01 \%$ dari keseluruhan jumlah rumah tangga miskin Kota Pekanbaru. Dari data tersebut jelas bahwa angka kemiskinan Kota Pekanbaru meningkat setiap tahun. Akibatnya, angka putus sekolah menurut Badan Pusat Statistik Kota Pekanbaru semakin meningkat. Dapat disimpulkan bahwa kemiskinan merupakan salah satu hambatan dalam pendidikan.

Menurut Ahmadi dan Supriyono (2004:88) keadaan ekonomi yang miskin akan menimbulkan: 1) kurangnya alat-alat belajar, 2) kurangnya biaya yang disediakan oleh orangtua, dan 3) tidak mempunyai tempat belajar yang baik. Menurut Sobur (2011:249) "Pada keluarga yang kondisi ekonominya relatif kurang, boleh jadi menjadi penyebab anak kekurangan gizi dan kebutuhankebutuhan anak mungkin tidak dapat terpenuhi. Selain itu, faktor kekurangan ekonomi menyebabkan suasana rumah menjadi muram yang pada gilirannya menyebabkan hilangnya kegairahan anak untuk belajar. Namun hal ini sebetulnya bukan sesuatu yang mutlak, terkadang faktor kesulitan ekonomi ini justru bisa menjadi cambuk atau pendorong bagi anak untuk lebih berhasil. Sebaliknya, bukan berarti pula keadaan ekonomi berlebihan tidak akan menyebabkan kesulitan belajar. Pada tingkat ekonomi yang berlebihan, yang biasanya menjadi alat untuk memenuhi semua kebutuhan anak, bukan tidak mungkin bisa menyebabkan berkurangnya perhatian anak terhadap kegiatan belajar. Karena perhatian anak justru lebih tertuju pada aspek kesenangan, misalnya terlalu seringnya mengunjungi tempat-tempat hiburan, atau karena sebagian besar waktunya habis untuk bermain dengan alat-alat permainan yang beraneka ragam.

Teori di atas menjelaskan bahwa faktor yang dapat mempengaruhi anak adalah tingkat kebahagiaan anak dengan kondisi keluarganya. Seperti perhatian orangtua, fasilitas, dan sebagainya yang anak miliki. Kecenderungan yang terjadi adalah anak yang berasal dari keluarga miskin memiliki penilaian yang rendah diri seoptimal dan semaksimal terhadap kebahagiaan hidupnya. Tingkatan atau kadar kebahagiaan yang dirasakan individu satu akan berbeda dengan individu lain. Hal ini dipengaruhi oleh halhal yang menjadikan individu tersebut bahagia seperti keluarga yang harmonis, teman-teman atau lingkungan yang hangat, status sosial ekonomi, dan sebagainya. Namun seringkali kebahagiaan seseorang hanya diukur berdasarkan keterpenuhan kebutuhan dasar saja seperti kebutuhan sandang, pangan, dan papan (status ekonomi sosial). Menurut hirarki kebutuhan Maslow (1943:10):

"undoubtedly these physiological needs are the most pre-potent of all needs. What this means specifically is, that in human being who is missing everything in life in an extreme fashion, it is most likely that the major motivation would be the physiolgical needs rather than any others. A person who is lacking food, safety, love, and esteem would most probably hunger for food more strngly than anything else."

Kebutuhan-kebutuhan pada tahap lebih tinggi (kebutuhan merasa aman dan terlindung dari bahaya, kebutuhan merasa diterima dan disayangi, kebutuhan akan rasa harga diri dan menjadi independen, kebutuhan akan informasi, kebutuhan mengerti dan memahami, kebutuhan menghayati keindahan, dan kebutuhan mengembangkan mungkin) tidak akan dirasakan dan dihayati kalau kebutuhan pada tahap di bawahnya tidak terpenuhi secara memuaskan (kebutuhan fisiologis yang mana bagi keluarga miskin sulit untuk memenuhinya). Berdasarkan 
pendapat tersebut dapat disimpulkan bahwa keluarga miskin kurang merasakan kebahagiaan.

Pada umumnya seseorang merasa dan berpikir bahwa kebahagiaan hidup yang diinginkannya terlepas dari bagaimana orang lain melihatnya. Fenomena ini yang kemudian disebut dengan subjective well being, yang merujuk pada fakta bahwa orang tersebut secara subjective percaya kehidupannya diinginkan, menyenangkan, dan baik. Diener (2009:12-13) mengemukakan:

"definitions of well-being and happiness can be grouped into three categories. First, well-being has been defined by external criteria such as virtue or holiness. Second, social scientists have focused on the question of what leads people to evaluate their lives in positive terms. A third meaning of happiness comes closest to the way the term is used in everyday discourse-as denoting a preponderance of positive affect over negative affect."

Berikutnya Prawitasari (2011:235) mengatakan bagi orang Indonesia, kesejahteraan subjektif seolah-olah hanya dapat dicapai bila orang sudah mampu memenuhi kebutuhan dasar seperti pangan, sandang, papan, dan seks. Dengan kata lain, kesejahteraan subjektif dianggap otomatis tercapai apabila orang sudah punya pekerjaan dan penghasilan tetap (terutama untuk memenuhi kebutuhan dasar) serta dapat hidup berpasangan. Dalam kerangka itu, peristiwa di luar dirinya, terutama reaksi emosi orang lain dalam kehidupan sosial, seolah-olah tidak bermakna dan tidak berpengaruh terhadap kesejahteraan subjektifnya. kesimpulannya, orang yang kaya memiliki kadar kesejahteraan subjektif yang lebih tinggi daripada orang yang miskin.

Berdasarkan permasalahan di atas, maka peneliti tertarik untuk melakukan penelitian tentang Analisis Subjective Well-Being Anak Usia Dini yang Berasal dari Keluarga berstatus Ekonomi Sosial Rendah di kota Pekanbaru".

\section{TINJUAN PUSTAKA}

Kesejahteraan subjektif atau dikenal dengan subjective well being didefinisikan oleh beberapa ahli di antaranya Lerner, Easterbrooks dan Mistry (2003:609), "Subjective well-being is viewed as a person's global evaluation of the quality of his or her life. High subjective well-being is regarded as indicating that the person successfully manages his or her life and ages well".

Pendapat di atas mengemukakan bahwa kesejahteraan subjektif dilihat dari bagaimana seseorang melihat kualitas keseluruhan hidupnya. Seseorang yang memiliki kesejahteraan subjekif tinggi adalah mereka yang dapat menghargai dan sukses dalam menata kehidupan.

Selanjutnya Purnamawati (2007:9) menyatakan bahwa well being merupakan sebuah konstruk kompleks yang lebih memusatkan perhatian pada pengalaman dan fungsi optimaldan penelitian tentang hal tersebut selama ini didasarkan pada dua perspektif yaitu perspektif hedonik dan eudaimonik. Perspektif hedonis adalah perspektif yang berfokus pada pengalaman subjektif individu mengenai kebahagiaan dan kepuasan hidupnya. Pengalaman subjektif tersebut meliputi persepsi tentang hal-hal yang menarik dalam hidup, kebahagiaan, dan kepuasan hidup.

Sedangkan perspektif eudaimonis lebih berfokus pada pemungsian psikologis, penyadaran diri, pengembangan diri, dan pemenuhan potensi individu yang bersifat jangka panjang serta membutuhkan usaha, kedisiplinan, dan pengorbanan. Seiring berkembangnya ilmu pengetahuan, perspektif hedonis dan eudamonis melahirkan dua konsep baru mengenai well-being yaitu: subjective well-being dan psychological well-being. Pendekatan 
hedonis yang menjadi landasan subjective well-being.

Menurut Diener (2009:13) definisi kesejahteraan subjektif dapat dilihat dari tiga sudut pandang yaitu:

the area of subjective well-being has three hallmarks. 1) it is subjective. It resides within the experience of the individual. Notably absent from definitions of SWB are necessary objective conditions such as health, comfort, virtue, or wealth. Although such conditions are seen as potential influences on $S W B$, they are not seen as an inherent and necessary part of it. 2) subjective well-being includes positive measures. It is not just the absence of negative factors, as is true of most measures of mental health. However, the relationship between positive and negative indices is not completely understood. 3) the subjective well-being measures typically include a global assessment of all aspects of a person's life.

Berdasarkan pendapat tersebut dapat disimpulkan makna kesejahteraan subjektif (self well-being) yaitu:

1) seseorang yang memiliki penilaian yang lebih tinggi tentang kebahagiaan dan kepuasan hidup, cenderung bersikap sepertinya mereka lebih bahagia dan lebih puas,

2) orang lain juga merasa orang-orang itu lebih bahagia dan lebih puas,

3) kesejahteraan subjektif mengacu pada bagaimana orang menilai kehidupan mereka dan termasuk beberapa variabel seperti kepuasan hidup, kurangnya depresi, kegelisahan, suasana hati, dan emosi positif.

\section{Faktor-faktor yang mempengaruhi Subjective Well Being}

Pada umumnya terdapat faktor yang dominan mempengaruhi subjective well being dalam diri seseorang. Menurut Hoorn (2007) faktor-faktor tersebut adalah: 1) faktor kepribadian, 2) faktor konteks dan situasi, 3) variabel demografis, 4) faktor lingkungan, 5) faktor ekonomi, dan 6) strategi coping. Untuk lebih memahami faktor-faktor tersebut, penulis membahas makna dari masing-masing aspek sebagaimana berikut.

1) Faktor Kepribadian

Setiap individu memiliki karakteristik kepribadian yang berbeda. Kepribadian sangat berpengaruh terhadap kesejahteraan subjektif. Salah satu penelitian yang melihat hubungan antara faktor kepribadian dengan subjective well being kembar identik dan tidak identik yang dibesarkan bersama dan dibesarkan terpisah. Hasil penelitian ini menunjukkan bahwa $40 \%$ variasi emosi positif dan 55\% variasi emosi negatif yang ditunjukkan atau yang nampak pada individu tergantung pada gen yang diwariskan. Selain itu, kepribadian yang berbeda akan memiliki kesejahteraan subjektif yang berbeda pula.

2) Faktor Konteks dan Situasi

Orang yang memiliki tubuh sehat akan merasakan kesejahteraan subjektif yang lebih tinggi dibandingkan dengan yang tidak sehat atau menderita suatu penyakit.

3) Variabel Demografis

Demografis juga memberikan pengaruh yang kuat pada kesejahteraan subjektif. Demografis merupakan perkembangan individu yang di dalamnya termasuk faktor jenis kelamin dan usia.

4) Faktor Lingkungan

Lingkungan juga dapat mempengaruhi kesejahteraan subjektif. Lingkungan yang aman dan tenteram akan membuat seseorang memiliki kesejahteraan subjektif yang tinggi.

5) Faktor Ekonomi

Orang kaya akan memiliki kesejahteraan subjektif yang lebih tinggi dibandingkan orang miskin.

6) Strategi Coping

Strategi coping menunjuk pada suatu usaha individu untuk mengatasi segala sesuatu yang berhubungan dengan sumber tekanan atau mengendalikan reaksi individu terhadap sumber tekanan tersebut 
dengan cara menirukan hal-hal yang dilakukan oleh orang lain.

Aspek yang terdapat dalam pengukuran kesejahteraan subjektif menurut Ozmete (2011:55) adalah kepuasan hidup, kehadiran efek positif, dan ketidakhadiran efek negatif. Kemudian menurut Diener, Suh, dan Oishi (1997) ada tiga komponen utama pada kesejahteraan subjektif yaitu kepuasan hidup (life satisfaction), perasaan positif (positive affect), dan perasaan negatif (negative affect). Ketiga komponen ini memiliki hubungan satu sama lain yaitu pada kepuasan hidup seperti rekreasi, cinta, persahabatan, dan sebagainya. Perasaan positif dikelompokkan dalam emosi-emosi spesifik seperti kegembiraan, kasih sayang, kebanggaan, dan sebagainya. Sedangkan perasaan negatif dapat dikelompokkan dalam emosi-emosi spesifik seperti malu, rasa bersalah, sedih, marah, dan kecemasan. Komponen kesejahteraan subjektif menurut Diener, Suh, dan Oishi (1997) diuraikan sebagai berikut.

1) Kepuasan Hidup

Kepuasan sendiri bisa dibagi menjadi beberapa daerah kepuasan seperti rekreasi, cinta, pernikahan, persahabatan, dan lain sebagainya. Keseluruhan dari kesejahteraan subjektif yang dirasakan seseorang tergantung pada beberapa macam daerah kepuasan (domainsatisfaction) seperti kesehatan, situasi finansial, atau keuangan, pekerjaan, waktu luang, tempat tinggal, dan lingkungan.

a) Kepuasan pada Pekerjaan

Kepuasan pada pekerjaan tergantung pada usia dan jenis kelamin. Selain itu, pendapatan yang tinggi diterima setelah bekerja akan menambah kesejahteraan subjektif pada diri seseorang.

b) Kepuasan pada Keuangan

Kepuasan pada keuangan akan menimbulkan berbagai efek dalam kehidupan seperti menetapkan jumlah anak. Begitu pula ibu rumah tangga memiliki kepuasan pada keuangan yang rendah terlihat dari afek negatif yang ditunjukkan.

c) Kepuasan pada Tempat Tinggal

Pengeluaran untuk keperluan tempat tinggal mempunyai pengaruh terhadap kepuasan. Biaya yang mahal akan berdampak pada kepuasan yang rendah. Selain itu, juga berpengaruh pada anggota keluarga.

d) Kepuasan pada Kesehatan

Seseorang dengan tingkat pendidikan yang tinggi akan lebih merasakan kepuasan di bidang kesehatan. Seseorang yang berpendidikan tinggi akan memiliki gaya hidup sehat. Orang yang bekerja akan merasakan kepuasan yang lebih tinggi di bidang kesehatan daripada yang tidak bekerja.

e) Kepuasan pada Waktu Luang Jam kerja yang panjang akan menurunkan kadar kepuasan terhadap waktu luang. Seseorang akan bisa menikmati waktu luangnya jika sendirian, sedangkan kepuasan pada waktu luang akan menurun apabila seseorang dalam keadaan tidak sendirian.

f) Kepuasan pada Lingkungan

Kepuasan pada lingkungan tergantung pada kehidupan seseorang. Jika dikaitkan dengan pendapatan maka orang yang mempunyai pendapatan tinggi akan merasakan kepuasan dalam lingkungannya. Begitu pula sebaliknya dengan pendapatan rendah maka individu tidak akan merasakan kepuasan terhadap lingkungannya.

2) Afek Positif

Afek positif atau menyenangkan yang dapat mempengaruhi kesejahteraan subjektif adalah kegembiraan, kasih sayang, kebahagiaan, sukacita, dan kebanggaan.

3) Afek Negatif

Afek negatif atau tidak menyenangkan yang dapat mempengaruhi kesejahteraan subjektif adalah perasaan bersalah, perasaan malu, kesedihan, 
kecemasan, kemarahan, tekanan, dan iri hati.

Sosial ekonomi menurut Abdulsyani (1994) adalah kedudukan atau posisisesorang dalam kelompok manusia yang ditentukan oleh jenis aktivitasekonomi, pendapatan, tingkat pendidikan, jenis rumah tinggal, dan jabatandalam organisasi, sedangkan menurut Soerjono Soekanto (2001) sosialekonomi adalah posisi seseorang dalam masyarakat berkaitan denganorang lain dalam arti lingkungan pergaulan, prestasinya, dan hak-hak sertakewajibannya dalam hubunganya dengan sumber daya.

Berdasarkan beberapa pendapat diatas, batasan keluarga dikatakan berstatus sosial ekonomi rendah adalah yang memenuhi kriteria indikator berikut:

1. Tingkat pendidikan Orangtua: maksimal SMA,

2. Tingkat pendapatan : di bawah UMR kota Pekanbaru (Rp. 2.100.000),

3. Jenis tempat tinggal : Rumah semi permanen, menyewa, dan disesuaikan dengan fakta lapangan.

\section{METODOLOGI PENELITIAN}

Metode penelitian yang digunakan adalah kuantitatif deskriptif dengan menggunakan analisis statistik.

Penelitian ini dilaksanakan di Kota Pekanbaru, dengan waktu penelitian mulai dari bulan Juni 2017 sampai dengan bulanMei 2018.

Menurut Arikunto (2003), populasi adalah keseluruhan subjek atau objek penelitian. Adapun populasi penelitian ini yaitu seluruh Anak Usia dini yang berasal dari keluarga berstatus ekonomi rendah pada catatan BPS Kota Pekanbaru. Sampel adalah bagian dari jumlah dan karakteristik yang dimiliki oleh populasi tersebut. Karena populasi besar, maka peneliti tidak mungkin mempelajari semua yang ada pada populasi karena keterbatasan dana, tenaga, dan waktu. Peneliti dapat menggunakan sampel yang diambil dari populasi itu. Teknik sampling yang dipakai dalam penelitian ini yaitu multistage random sampling yaitu teknik sampling yang menggunakan dua langkah atau lebih, sebagai berikut.

1. Berdasarkan Area

Penarikan sampel berdasarkan area yakni menarik sampel berdasarkan area tengah Kota Pekanbaru dan area pinggir Kota Pekanbaru. Area tengah Kota Pekanbaru danarea pinggir Kota Pekanbaru.

2. Berdasarkan besaran sampel

Langkah penentuan sampel selanjutnya adalah menentukan besaran sampel berdasarkan rumus Slovin:

$$
\begin{aligned}
& n=\frac{N}{1+N\left(d^{2}\right)} \\
& \text { Keterangan: } \\
& \mathrm{n} \quad=\quad \text { Besar sampel } \\
& \mathrm{N}=\quad \text { Besar populasi } \\
& \mathrm{d} \quad=\quad \text { Tingkat kesalahan } \\
& \text { Besaran } \quad \text { sampel yang menjadi }
\end{aligned}
$$
sampel penelitian berjumlah 30 orang anak yang berasal dari 12 kecamatan di kota Pekanbaru.

Analisis data menggunakan statistik deskriptif, sebelumnya peneliti mengolah data terlebih dahulu. Berdasarkan perhitungan rumus di atas, maka mean hipotetik $(\mu)$ dan standar deviasi hipotetik $(\sigma)$ dapat ditentukan dan sekaligus dibandingkan data empirik yang telah diperoleh. Selanjutnya untuk tingkat capaian responden pada masing-masing variabel dapat dideskripsikan dengan menggunakan kriteria penilaian masingmasing data yang mengacu kepada batasan yang dikemukakan oleh Azwar (2012:148) seperti tabel berikut ini.

\begin{tabular}{l|l}
\multicolumn{1}{c}{ Kategorisasi } & \multicolumn{1}{c}{ Rumus Norma } \\
Sangat Tinggi $(S T)$ & $\geq \mu+1,5 \mathrm{SD}$ \\
Tinggi $(T)$ & $(\mu+0,5 \mathrm{SD}) \mathrm{s} / \mathrm{d}<(\mu+1,5 \mathrm{SD})$ \\
Sedang $(S)$ & $(\mu-0,5 \mathrm{SD}) \mathrm{s} / \mathrm{d}<(\mu+0,5 \mathrm{SD})$ \\
Rendah $(R)$ & $(\mu-1,5 \mathrm{SD}) \mathrm{s} / \mathrm{d}<(\mu-0,5 \mathrm{SD})$ \\
Sangat Rendah $(S R)$ & $<(\mu-1,5 \mathrm{SD})$
\end{tabular}

\section{HASIL PENELITIAN DAN PEMBAHASAN}

Berikut ini merupakan hasil penggambaran tentang kondisi anak-anak yang menjadi subjek penelitian. 


\section{Gambaran Jumlah Subjek Penelitian}

Berdasarkan hasil angket ditemukan bahwa terdapat 18 orang lakilaki dan 12 orang perempuan yang berasal dari status ekonomi rendah. Siswa tersebut berusia 5-6 tahun.

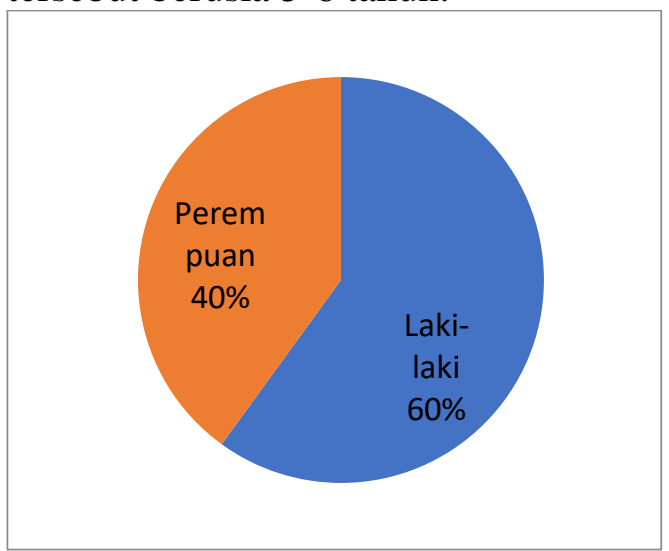

Gambar 1. Jumlah Anak

Dari gambar di atas terdapat $60 \%$ siswa laki-laki an $40 \%$ siswa perempuan berstatus ekonomi rendah yang berasal dari berbagai sekolah TK dan PAUD yang ada di kota Pekanbaru.

\section{Gambaran Penghasilan Orangtua Siswa}

Berdasarkan hasil angket diketahui bahwa penghasilan orangtua dari siswa yang menjadi objek penelitian mulai dari dibawah Rp. 1.000.000,00 sampai dengan Rp. 3.000.000,00. 12 orang memiliki penghasilan di bawah 1 juta rupiah, 12 orang memiliki penghasilan 1-2 juta rupiah dan 6 orang memiliki penghasilan 2-3 juta rupiah.

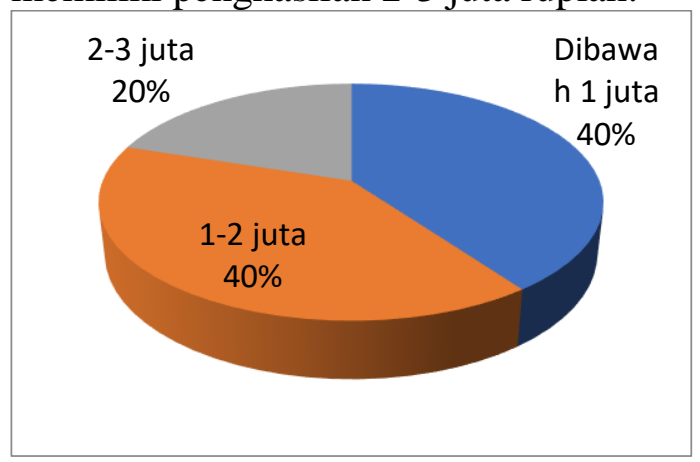

Gambar 2. Penghasilan Orang Tua

Dari gambar di atas terdapat $40 \%$ yang berpenghasilan dibawah 1 juta rupiah,
$40 \%$ berpenghasilan 1-2 juta rupiah dan $20 \%$ berpenghasilan 2-3 juta rupiah.

\section{Gambaran Kesejahteraan Subjektif Anak Ketika di Rumah \\ a. Perasaan Anak Saat di Rumah}

Dari hasil angket yang diberikan diketahui 18 orang anak yang merasa senang ketika berada di rumah, 6 orang anak merasa cukup senang ketika berada di rumah tetapi orangtua mereka sibuk mencari nafkah, dan 6 orang anak yang pendiam ketika berada di rumah.

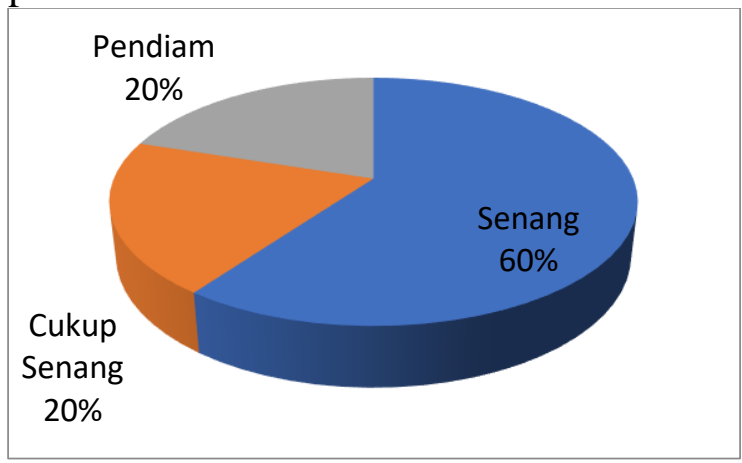

Gambar 3. Perasaan saat di rumah

Dari gambar di atas dapat diketahui bahwa $60 \%$ anak merasa senang ketika berada di rumah, $20 \%$ merasa cukup senang namun orangtua mereka sibuk mencari nafkah, sedangkan 20\% yang lain cendrung pendiam ketika berada di rumah.

\section{b. Hal yang Membuat Anak Senang}

Hal yang membuat anak senang yaitu suasana kekeluargaan, bermain dengan kakak atau adik, dan bermain bersama teman-teman.

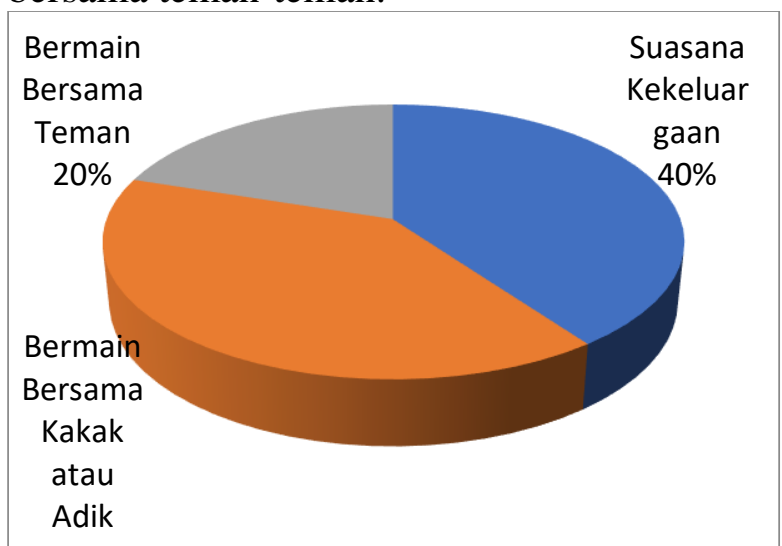

Gambar 4. Hal yang membuat senang 
Empat puluh persen anak merasa senang karena suasana kekeluargaan yang nyaman, empat puluh persen anak merasa senang karena bermain bersama kakak atau adik dan dua puluh persen karena bermain bersama teman-teman.

\section{c. Hal yang Membuat Anak Lebih Senang dari Biasanya}

Hal yang membuat anak lebih senang dari biasanya yaitu berkumpul bersama keluarga, disayangi orangtua, ketika dibelikan makanan, dibelikan mainan baru.

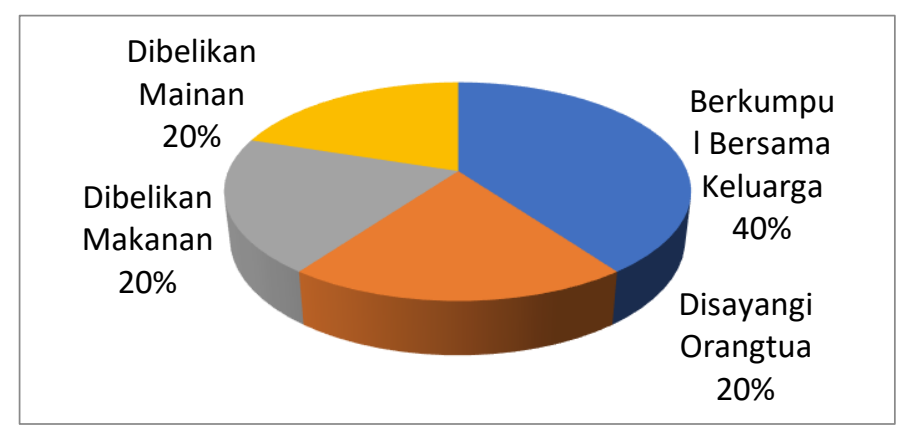

Gambar 5. Hal yang membuat lebih senang

\section{d. Hal yang Membuat Anak Sedih}

Hal yang membuat anak sedih yaitu diusili oleh orang lain, tidak ada teman bermain, disuruh cepat-cepat ke

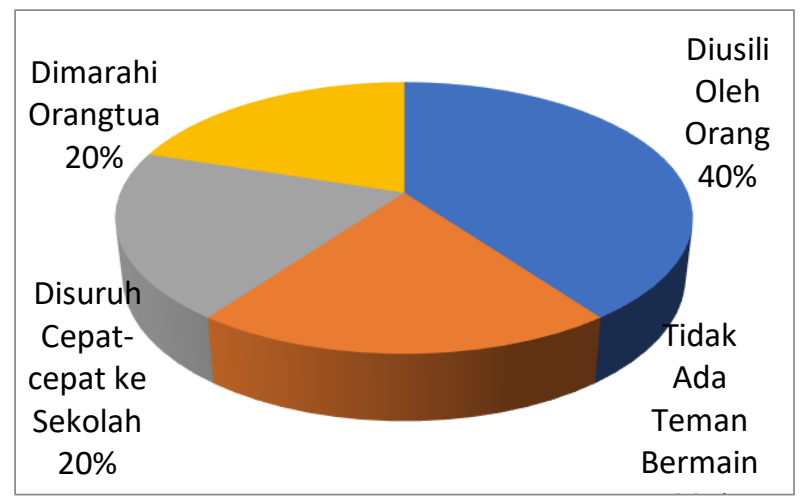

sekolah, dan dimarahi orangtua.

Gambar 6. Hal yang membuat anak sedih

Empat puluh persen anak merasa sedih ketika diusili oleh orang lain, dua puluh persen ketika tidak ada teman bermain, dua puluh persen ketika disuruh cepat- cepat ke sekolah, dan dua puluh persen ketika dimarahi orangtua.

\section{e. Kepada Siapa Anak Meminta Bantuan Ketika Menghadapi Masalah}

Ketika menghadapi masalah, anak meminta bantuan kepada Ibu, Ayah dan Ibu, dan Kakak.

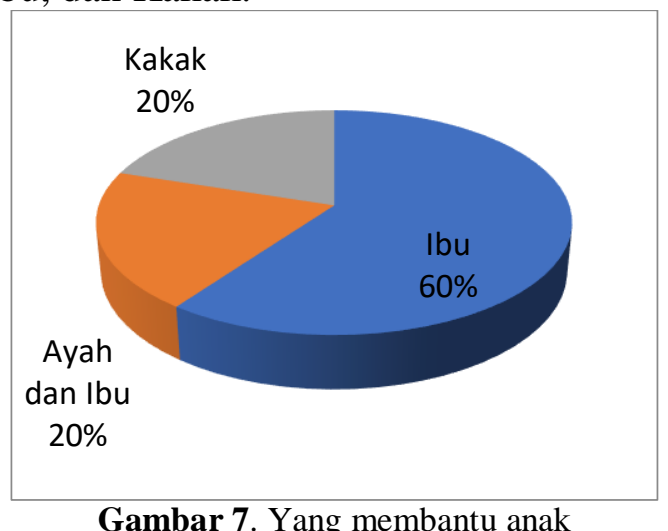

Ketika menghadapi masalah, $60 \%$ anak meminta bantuan kepada Ibu, 20\% anak meminta bantuan kepada Ayah dan Ibu, dan 20\% kepada Kakak.

\section{f. Bantuan yang Diberikan Ketika Mendapat Masalah}

Bentuk bantuan yang diberikan berupa hiburan, pendampingan, dan nasehat.

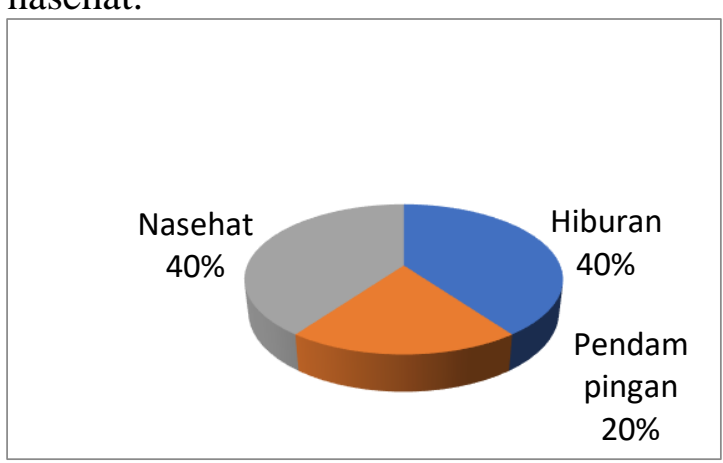

Gambar 8. Bantuan yang diberikan

Empat puluh persen mendapat bantuan atau perhatian ketika mendapat masalah melalui hiburan, dua puluh persen berupa pendampingan dan empat puluh persen berupa nasehat. 


\section{g. Kehidupan Anak Secara Umum}

Kehidupan anak secara umum ketika berada di rumah yaitu normal seperti anak yang lain, serba kekurangan dan hidup sederhana.

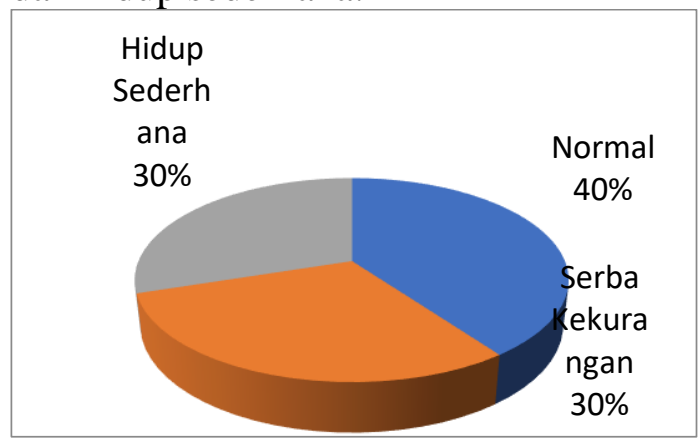

Gambar 9. Kehidupan secara umum

Empat puluh persen anak menjalani hidup secara normal atau layaknya anak yang lain, tiga puluh persen anak hidup serba kekurangan dan tiga puluh persen anak hidup sederhana.

\section{Gambaran Kesejahteraan Subjektif Anak Ketika di Sekolah \\ a. Perasaan Anak Saat di Sekolah}

Senang dan Sangat senang

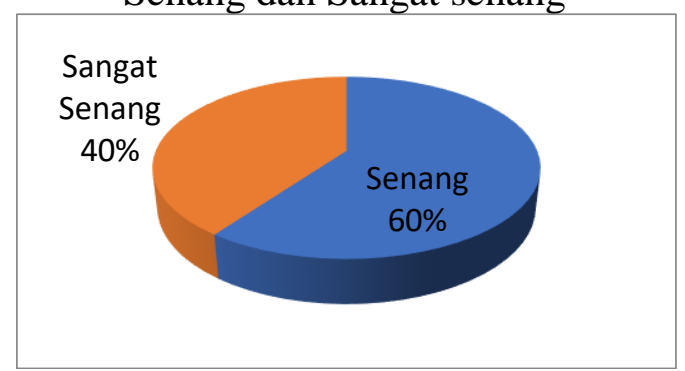

Gambar 10. Perasaan saat di sekolah

\section{b. Hal yang Membuat Anak Senang}

Bermain dengan teman-teman, bermain bersama teman-teman dan guru.

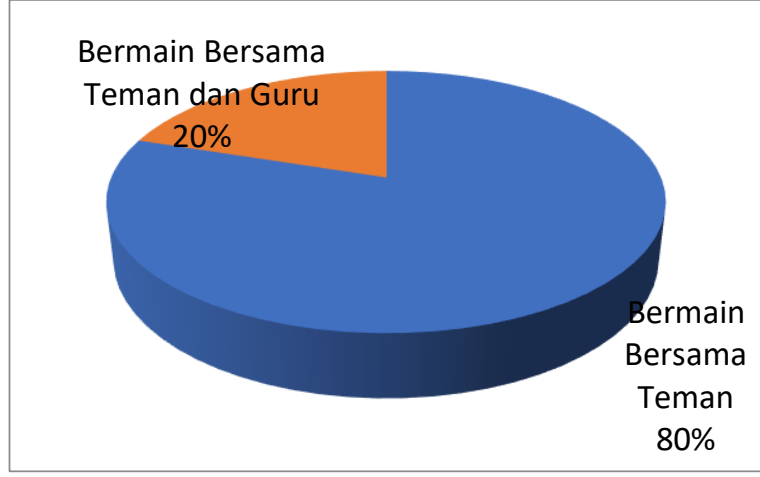

Gambar 11. Hal yang membuat senang

\section{c. Hal yang Membuat Anak Lebih Senang dari Biasanya}

Bercerita dengan pengalaman, saat outing class, saat ada teman berulang tahun, bermain, melakukan hal baru.

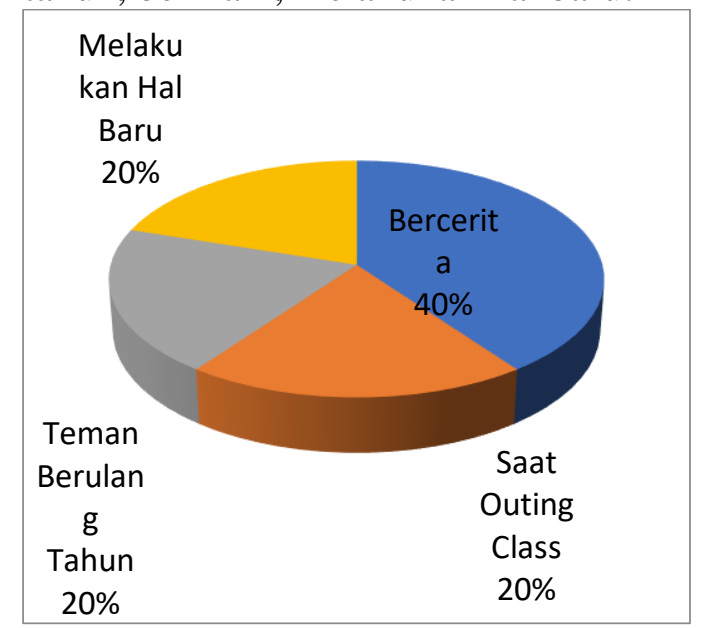

Gambar 12. Hal yang membuat lebih senang

\section{d. Hal yang Membuat Anak Sedih}

Diganggu teman, bertengkar dengan teman, tidak ada teman bermain.

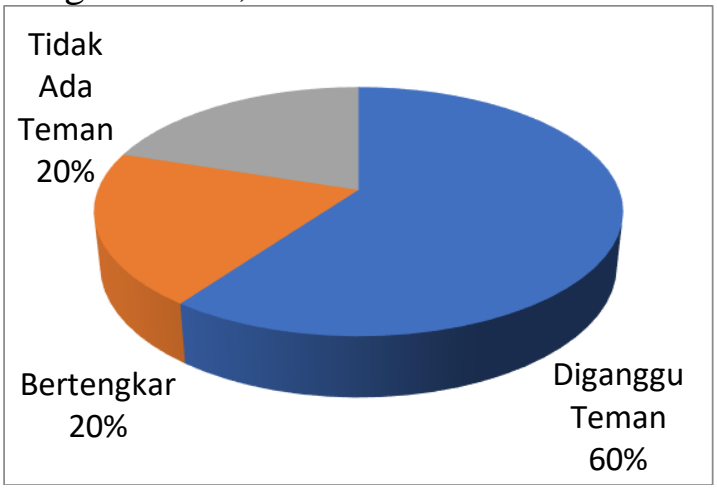

Gambar 13. Hal yang membuat sedih

\section{e. Alasan yang Membuat Anak Sedih}

Tidak memiliki teman, teman jahat, teman iseng, dan tidak dapat menyelesaikan tugas.

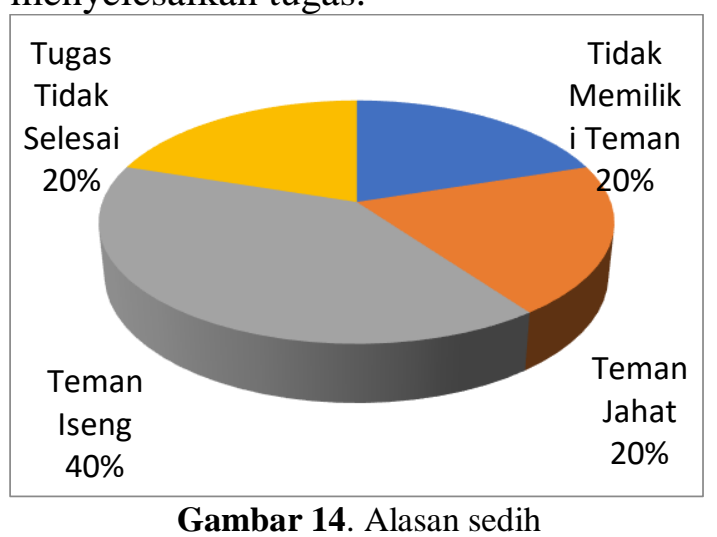




\section{f. Kepada Siapa Anak Meminta Bantuan Ketika Menghadapi Masalah}

Guru, pengelola, teman dekat.

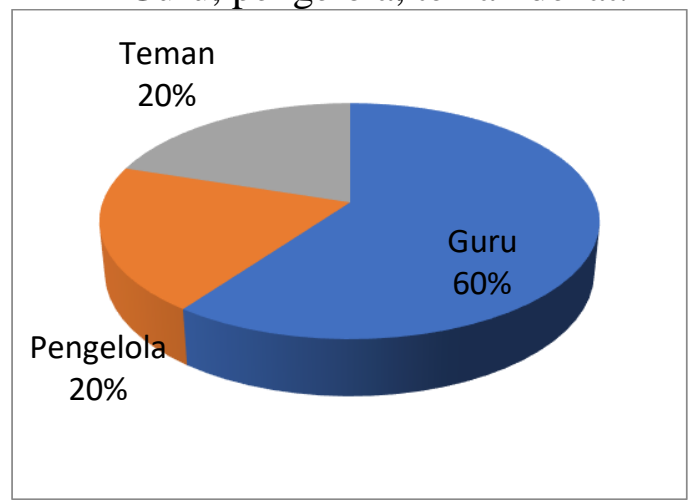

Gambar 15. Yang membantu anak

\section{g. Kehidupan Anak Secara Umum}

Normal, mampu bersosialisasi, pintar tapi pendiam.

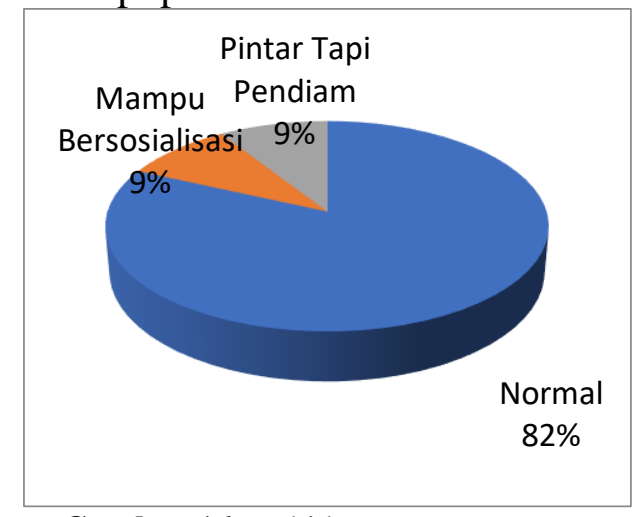

Gambar 16. Kehidupan secara umum

\section{Gambaran Kesejahteraan Subjektif Anak Ketika di Lingkungan Bermain}

a. Perasaan Anak Saat di Lingkungan Bermain

Perasaan anak saat berada di lingkunagan bermain yaitu sangat senang, senang, cukup senang.

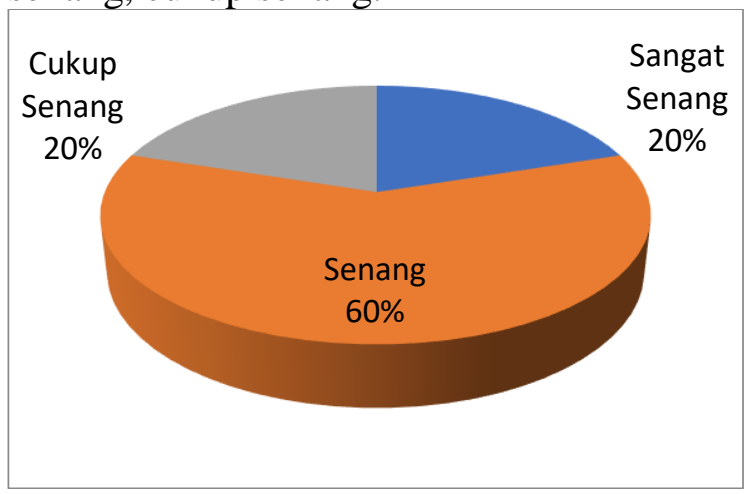

Gambar 17. Perasaan anak

\section{b. Hal yang Membuat Anak Senang}

Hal yang membuat anak senang yaitu kebebasan, banyak teman, diberi kesempatan oleh guru, suasana kebersamaan, menyalurkan minat dan bakat.

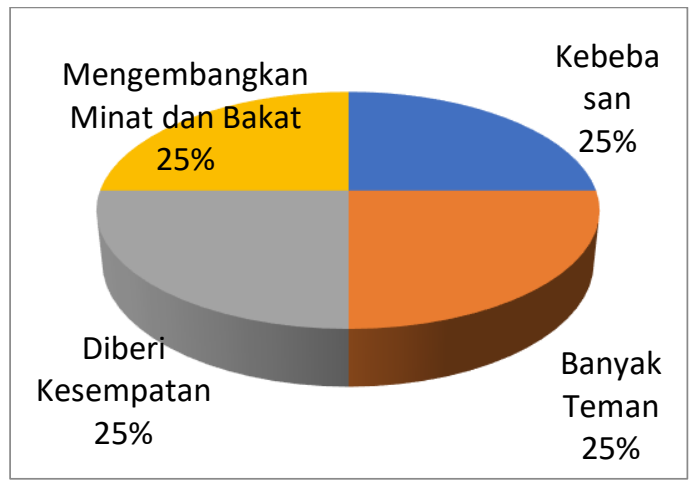

Gambar 18. Hal yang membuat anak senang

\section{c. Hal yang Membuat Anak Lebih Senang dari Biasanya}

Hal yang membuat anak lebih senang dari biasanya yaitu bermain, melakukan kegiatan baru.

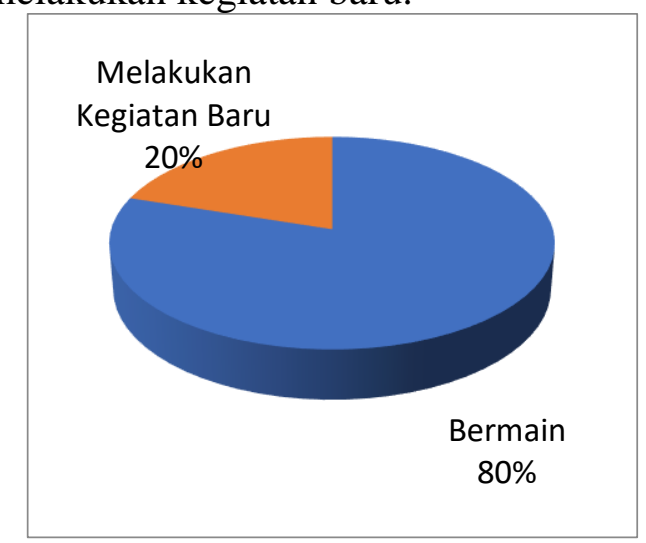

Gambar 19. Hal yang membuat lebih senang

\section{d. Hal yang Membuat Anak Sedih}

Hal yang membuat anak sdih yaitu diusili teman, bertengkar, dikucilkan.

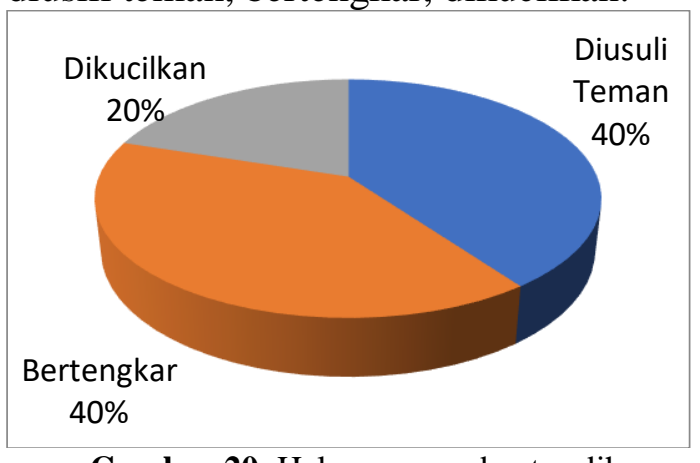

Gambar 20. Hal yang membuat sedih 


\section{e. Alasan Anak Sedih}

Alasan yang membuat anak sedih yaitu rebutan mainan, bertengkar, dikucilkan, tidak diberi kesempatan bermain.

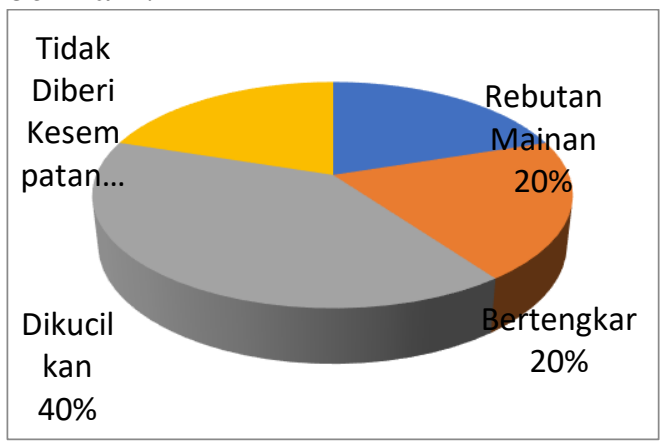

Gambar 21. Alasan sedih

\section{f. Kepada Siapa Anak Meminta Bantuan Ketika Menghadapi Masalah}

Yang memberikan bantuan kepada anak saat anak berada dalam masalah yaitu saudara, orangtua dan guru.

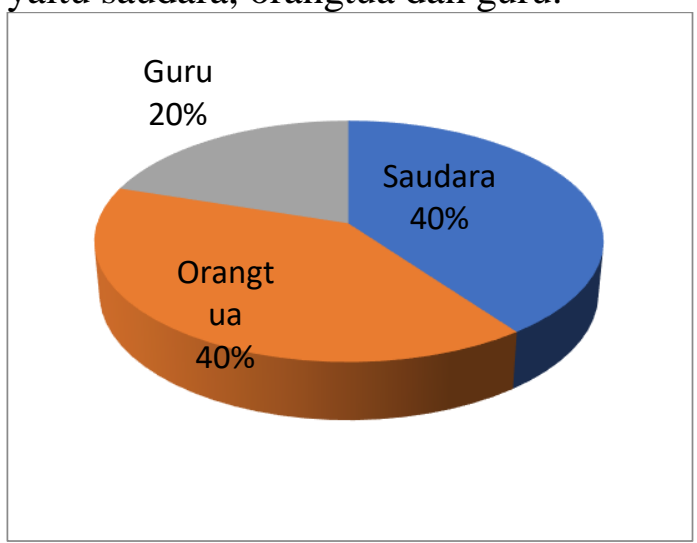

Gambar 22. Yang membantu anak

\section{g. Kehidupan Anak Secara Umum}

Kehidupan anak secara umum ketika di lingkungan bermain yaitu normal, senang, pendiam.

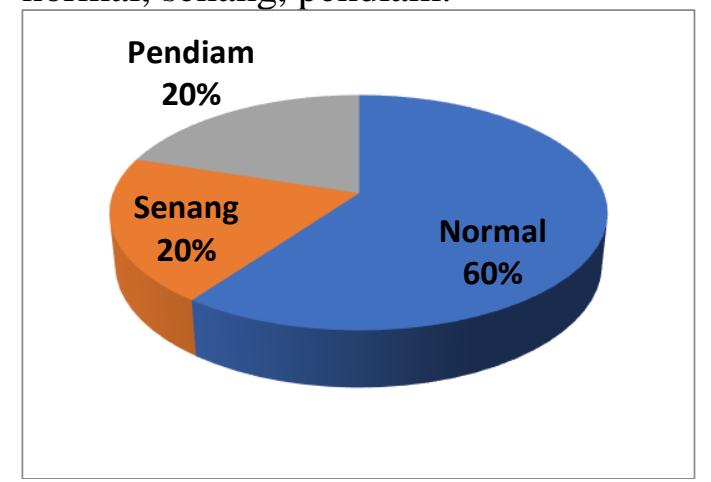

Gambar 23. Kehidupan anak secara umum

\section{KESIMPULAN}

Berdasarkan temuan penelitian diperoleh hasil bahwa tingkat kesejahteraan subjectif well-being anak usia dini tinggi meskipun berasal dari keluarga berstatus ekonomi rendah. Di tinjau dari tiga ranah lingkungan, lingkungan ruah, sekolah dan lingkungan masyarakat rata-rata anak tinggi kesejahteraan subjektifnya pada lingkungan sekolah (PAUD) karena banyak fasilitas bermain, banyak teman dan banyak menemukan hal-hal yang baru.

\section{DAFTAR PUSTAKA}

Abdulsyani. (1994). Sosiologi Skematika, Teori dan Terapan. Jakarta: BumiAksara.

Ahmadi, Abu dan Supriyono, Widodo. (2007). Psikologi Belajar. Jakarta: Rineka Cipta.

Diener, Ed. (2009). Subjective WellBeing(The science of well-Being). New York: Springer.

Diener, Ed., Suh, Eunkook, dan Oishi, Shigehiro. (2007). Recent Findings On SWB, Indian Journal of Clinical Psychology, (Online), http://edener@s.psich.uiuc.edu, diakses 18 Januari 2015.

Hoorn, Andre van. (2007). "A short Introduction to Subjective WellBeing: (Its measurement correlates and policy uses)". Radboud University Nijmegen.

Lerner, Richard M., Easterbrooks, M.A., dan Mistry, Jayanthi. (2008). Handbook Of Psychology (Developmental psychology). Canada: John Wiley and sons, Inc.

Maslow, A.H. (2007). A Theory of Human Motivation. India: Nalanda Digital Library.

Ozmete, Emine. (2011). "Subjective Well Being (As research on life statisfaction as cognitive component of subjective well 
being)".Tidak diterbitkan. Vol. 3 dan 4.

Purnamawati. (2007). "Gambaran Psychological Well Being pada Pegawai Negeri Sipil Pria yang mengalami Pensiun di Usia Dewasa Madya". FPSI UI.

Sobur, Alex. (2011). Psikologi Umum. Bandung: Pustaka Setia.

Soerjono Soekanto. (2002). Sosiologi Suatu Pengantar. Jakarta:Rajawali Press 